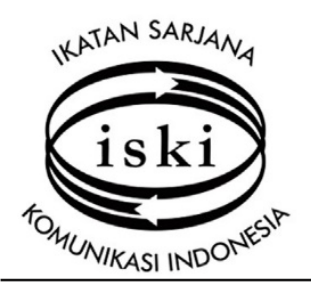

J $U R \quad R \quad N \quad A \quad L$

\title{
Social Network Analysis: \#BlackLivesMatter Distribution at Actor Level and System Level
}

\author{
http://dx.doi.org/10.25008/jkiski.v6i2.577 \\ Edy Prihantoro $^{1^{*}}$ Rizky Wulan Ramadhani $^{2}$ \\ ${ }^{1,2}$ Department of Communication Science, Universitas Gunadarma \\ Jl. Margonda Raya No. 100, Depok 16424 - Indonesia \\ *Corresponding author: edipri@staff.gunadarma.ac.id
}

Submitted: August 10, 2021, Revised: September 12, 2021, Accepted: November 30, 2021

Accredited by Kemristekdikti No. 28/E/KPT/2019

\begin{abstract}
\#BlackLivesMatter accompanies several cases of discrimination against the black community. The hashtag was spread by actors who have great influences on Twitter users. The actors create communication network which connected to each other to form opinions about the Black Lives Matter movement. Researchers conducted a study to determine the distribution of \#BlackLivesMatter at the actor level for the period 20-27 April 2021 in Twitter. The study used quantitative methods and a positivistic paradigm with a Social Network Analysis (SNA) approach. The results show that the actor with the highest degree of centrality is @ jeanmessiha with 238 interactions, the actor with the highest betweenness centrality is @helloagain0611 with a value of 0.000049 , the actor with the highest eigenvector centrality is @jeanmessiha with a value of 1 and there are 1,416 actors who have closeness centrality. \# BlackLivesMatter has a low diameter value so that it spreads quickly but not too widely, not much reciprocity occurs, not concentrated in one dominant cluster but spread widely in several clusters. The actors play a role in spreading diverse opinions regarding Black Lives Matter, thus creating free discussion in several clusters on Twitter. Opinion widely spread on Twitter creates public opinion regarding the Black Lives Matter movement.
\end{abstract}

Keywords: \#BlackLivesMatter; communication network; social network analysis; twitter; system level

\section{Introduction}

\#BlackLivesMatter was first posted on Facebook in 2013 by Alicia Garza and her sister. Alicia Garza in Lebron (2017) said that she and her two sisters, Patrisse Cullors and Opal Tometi, made Black Lives Matter as an invitation to the public to demand justice for Trayvon Martin and other black people who have been discriminated. Trayvon Martin was a black young man who was killed by a white police officer, George Zimmerman, who was acquitted of charges due to lack of evidence.

At first \#BlackLivesMatter wasn't very familiar for the public. However, when the shooting of Mike Browns in 2014 sparked demonstrations, the hashtag was increasingly used by social media users. These hashtags are used to accompany topics such as fatal incidents with police, acts of violence in general, police and law enforcement, national politicians and political parties, race and protests (Anderson et al., 2018).

\#BlackLivesMatter reached its peak with the murder of George Floyd in 2020. Floyd's death caused by a white police officer named Derek Chauvin was successfully uploaded as many as 47.8 million during the period from May 26 to June 72020 . Even on May 28 the hashtag was uploaded 8.8 million, making it the highest number of uses since its appearance on Twitter (Anderson et al., 2020). 
On April 20, 2021, Chauvin was found guilty of Floyd's murder. In addition, there was a murder of a black citizen named Ma'khia Bryant by a white police officer. Twitter users express their opinions using \#BlackLivesMatter for the period $20-27$ April 2021. They are connected to each other and create a communication network on Twitter. The term communication network refers to the pattern of communication among a group of designated individuals (Feeley et al., 2018). According to Rakhman et al. (2021) communication network is used to determine the relationship or relations of an actor expressed in institutions, companies, countries and others that are in a certain social structure. Actors can influence the opinions of other actors if their opinions are considered credible.

The \#BlackLivesMatter communication network for the period 20 - 27 April 2021 can be viewed at actor level and system level. The actor level measures the interaction, proximity and role of actors in a communication network. The actors consist of various layers of society, ranging from politicians to activists who want to voice their opinions as well as discuss freely. The actors involved interact with each other which is marked by likes, retweets, retweet quotes and comments that determine the structure of the network created. The system level is a comprehensive picture of the network that better interprets the network structure and network characteristics (Kurniawan et al., 2020). The system level is used to measure density, reciprocity and concentration in a communication network.

The distribution of \#BlackLivesMatter at the actor level and system level can determine the dominant opinion in the communication network. According to Tjahyana (2019), opinions uploaded on social media are the same as opinions expressed formally in public institutions. So that the opinions spread on social media have an impact on the public's view of a movement. Black Lives Matter must be able to attract public support if it wants to continue to voice anti-discrimination against the black community. Important actors play a role in bringing public support.

Based on the explanation above, the researcher conducted a study entitled Social Network Analysis: \#BlackLivesMatter Distribution at Actor Level and System Level to determine the distribution of \#BlackLivesMatter at the actor level and system level using the Social Network Analysis (SNA) approach. SNA is one method to analyze the distribution of a hashtag at the actor level and the system level. A lot of research on SNA has been done in the field of communication science.

Rakhman et al. (2021) conducted a study entitled Analisis Sentimen dan Opini Digital Kampanye 3M di Masa Covid-19 Melalui Media Sosial Twitter which discussed the 3M Campaign. In that study, Rakhman et al. (2021) analyzed the communication network at the actor level and the system level. The results of the study indicate that important actors influence the mobility of Twitter users' opinions. Eriyanto (2019) compares the communication network of \#BubarkanKPAI and \#KamiBersamaKPAI in a study entitled Hashtags and Digital Movement of Opinion Mobilization: A Social Network Analysis/SNA Study on \#BubarkanKPAI vs \#KamiBersamaKPAI Hashtags. The results showed that there was no dominant actor in the \#BubarkanKPAI distribution. Rakhman, Ramadhani, \& Fatoni (2021) conducted a study entitled \# Gerakan Opini Digital \#Indonesiaterserah pada Media Sosial Twitter di Masa Pandemi Covid-19. The results of the study show that there are several important actors who move opinion using \#Indonesiaterserah.

Researchers conducted different studies with some of the studies above. The researcher aims to find out the distribution of \#BlackLivesMatter at the actor level and the system level without looking at the movement of opinion. The researcher analyzed the actors involved and their uploads in the \#BlackLivesMatter communication network for the period 20-27 April 2021. In addition, the researchers also used hashtags that are used globally so that they have a wider network and consist of actors who have various backgrounds spread into several clusters.

\section{Theoretical Framework Hashtag}

Hashtags were first used in 2008 and have many functions. According to Bristol et al in Maclean et al. (2013) hashtags can be used to help for specific areas of discussion. In addition, Maclean et al. (2013) added that hashtags can be used as a back channel for conversations related to an event, both local and global events. Hashtags play an important role in communication networks in expressing opinions that form communities to discuss the same topic even though they don't know each other. According to Eriyanto (2019), hashtags 
can be used to show the emotion of an opinion, to state problems, the parties involved and solutions that can be applied. Twitter recommends limiting hashtag use to two or less per tweet (Driver, 2021). Using too many hashtags makes other users will not interact with the tweet because it is considered annoying.

\section{Communication Network}

Rogers and Kincaid in Wicaksono et al. (2019) states that communication networks describe interpersonal communication from opinion leaders and followers who have relationships related to certain topics in a social system. According to Utami (2018), a communication network is a channel used to convey messages from one person to another. A communication network consists of actors, links and several other elements. The link is represented by a line connecting the actors.

According to Eriyanto in Rakhman, Ramadhani, \& Kuncoroyakti (2021), communication network is a simple analytical method that can explain social networks and their structure. As a method, the communication network has the following advantages: (1) The communication network describes the formation of the communication phenomenon; (2) Communication networks can show the position and strength of actor; (3) Network communication shows network comparison.

\section{Social Network Analysis (SNA)}

SNA can be used to find out which actors (nodes) are involved in a relationship that occurs, who is related to the actors, or the gap and range of each actor. According to Oktora and Alamsyah in Bakry (2020) SNA is used to study networks, ideas and actors involved in an environment. At the actor level, the relationship between actors has several sizes, namely: (1) Degree centrality is the number of interactions or ties that occur between actors (nodes); (2) Closeness centrality is used to calculate the average distance or proximity between actors with the highest value of 1.00; (3) Betweenness centrality calculates how often a node is passed by another node to go to a certain node in the network (Setatama \& Tricahyono, 2017); (4) Eigenvector centrality is a measure of how important actors are in a network.

While at the system level, a network has several sizes such as: (1) Diameter is the furthest distance that can be reached by an actor in a communication network; (2) Density shows the density of a communication network which is characterized by the number of reciprocal interactions that occur between Twitter users; (3) Reciprocity is a two-way communication that occurs between Twitter users; (4) Modularity is a group or cluster that is created in a communication network; (5) Centralization is a picture of the concentration created in a communication network and diameter is the farthest location that can be reached by actors in a network (Eriyanto, 2014).

\section{Materials and Methodology}

This study uses a quantitative method with a Social Network Analysis approach to determine the distribution of \#BlackLivesMatter at the actor level and system level. This study uses a positivistic paradigm. According to Siyoto (2015), the positivistic paradigm is influenced by an empirical scientific perspective and becomes the basis for quantitative research. This type of research is descriptive. Descriptive research is a research method that seeks to describe the object or subject being studied according to what it is (Best dalam Samsu, 2017). The subject of this research is 2,500 tweets uploaded on $20-27$ April 2021 and the object of research is the distribution of \#BlackLivesMatter at the actor level and system level. The population in this study is all tweets uploaded using \#BlackLivesMatter on 20 - 27 April 2021 and the sample is 2,500 tweets using \#BlackLivesMatter obtained from crawling data using Netlytic.

\section{Result and Discussion}

\#BlackLivesMatter is uploaded on Twitter by actors such as politicians, NGOs or personal accounts to provide opinions related or not related to the new social movement Black Lives Matter. In the period 20-27 April 2021, Twitter users gave their opinions regarding several cases that befell the black community and discussed Floyd's death again because Chauvin was finally found guilty. The distribution of \#BlackLivesMatter can be seen at the actor level and system level to find out how wide, how long, how many actors are involved and who are the dominant actors involved in the hashtag communication network.

Analysis of the \#BlackLivesMatter Communication Network Actor Level for the Period 20 - 27 April 2021 Using Netlytic

At the actor level, the \#BlackLivesMatter communication network has measures of 
degree centrality, closeness centrality, betweenness centrality, and eigenvector centrality that affect the spread of opinion in the communication network using the hashtag. The distribution of \#BlackLivesMatter at the actor level is as follows:

Degree Centrality, is a measure used to find out how many interactions or bonds occur between actors who use certain hashtags or keywords. There are two directions in degree centrality, namely indegree and outdegree. Indegree is the number of interactions or ties that lead to certain actors or nodes and outdegree is the number of interactions or ties directed by one actor to another. An actor is said to be a dominant actor if he has a greater number of indegrees than outdegrees (Rakhman, Ramadhani, \& Fatoni, 2021). Based on data obtained from Netlytic and Gephi, actors who have a high degree of centrality in the \#BlackLivesMatter distribution are @jeanmessiha with 238 interactions, (a) cathygraphics2 with 64 interactions, @.JFSebastian146 with 60 interactions, (a)rubnpulido with 51 interactions, and @jordanchariton with 46 interactions. as shown in figure 1 and table 1 below:

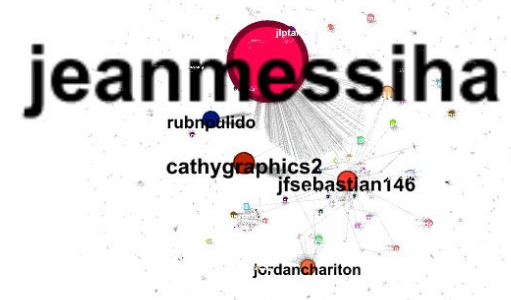

Figure 1. Degree Centrality of \#BlackLivesMatter Period 20 - 27 April 2021

Source: Gephi Software

Table 1. Degree Centrality of \#BlackLivesMatter Period 20 - 27 April 2021

\begin{tabular}{|c|l|c|}
\hline No. & Actors & $\begin{array}{l}\text { Degree } \\
\text { Centrality }\end{array}$ \\
\hline 1. & jeanmessiha & 238 \\
\hline 2. & cathygraphics2 & 64 \\
\hline 3. & jfsebastian146 & 60 \\
\hline 4. & Rubnpulido & 51 \\
\hline 5. & Jordanchariton & 46 \\
\hline
\end{tabular}

Sumber: Netlytic, 2021

@jeanmessiha posted a tweet satirizing the Black Lives Matter movement. The tweet then received a lot of likes, comments and replies showing the other actor's interactions with@jeanmessiha. High interaction makes the spread of these tweets to reach Twitter users widely. The other four actors are those who tweeted positive about the Black Lives Matter movement. These actors create a communication network with many actors in discussing the sub topic of Black Lives Matter. Actors with high interaction values managed to make positive opinions dominate the \#BlackLivesMatter communication network for the period 20 - 27 April 2021.

There are two directions in degree centrality, namely indegree and outdegree. According to Sataloff et al. (2011), indegree is the number of ties that lead to a particular actor.
The accounts above have been contacted by many other accounts as evidenced by the number of retweets, retweet quotes and likes. In the \#BlackLivesMatter communication network for the period 20 April to 27 April 2021, the actors with the highest indegree scores are@jeanmessiha with 238 indegree, @ cathygraphics2 with 64 indegree, @ Rubnpulido with 51 indegree, @ Jordanchariton with 46 indegree and (a)Bradbeauregardj with 40 indegree. Rakhman, Ramadhani, \& Kuncoroyakti (2021) stated that a high indegree value indicates that the actor is often accessed or contacted by other actors in a communication network. Actors with the highest indegree in the \#BlackLivesMatter communication network are shown in table 2 below: 
Table 2. The Actors with Highest Indegree in Communication Network of \#BlackLivesMatter Period 20 - 27 April 2021

\begin{tabular}{|l|l|l|}
\hline \multicolumn{1}{|c|}{ No. } & Actors & Indegree \\
\hline 1. & jeanmessiha & 238 \\
\hline 2. & cathygraphics 2 & 64 \\
\hline 3. & Rubnpulido & 51 \\
\hline 4. & Jordanchariton & 46 \\
\hline 5. & Bradbeauregardj & 40 \\
\hline
\end{tabular}

Sumber: Netlytic, 2021

Meanwhile, actors with highest outdegrees in the \#BlackLivesMatter communication network for the period 20-27 April 2021 are@jfsebastian146 with outdegree 60, @radio_undergr with outdegree 16, @ bridget69176622 with outdegree 16, @idek3339 with outdegree 13 and (a)collee 02775798 with outdegree 12. Outdegree is the number of ties that an actor directs to another actor. The highest outdegree indicates that the actor has a level of popularity in a communication network to contact, access, or reply to within the communication network (Rakhman, Ramadhani, \& Fatoni, 2021).

@ jeanmessiha is the only dominant actor in the \#BlackLivesMatter communication network because it has an indegree value higher than outdegree.@jeanmessiha many contacted and contacted by other actors by retweeting or mentioning. However, not all accounts with high engagement values have an interest in the BLM movement. For example, the @aradio_undergr account uploads tweets that are not related to the BLM movement or antiracism and only uses it as a tweet format. @radio_undergr took advantage of the quite popular \#BlackLivesMatter to promote the underground music they tweeted on the account. Actors with the highest outdegree in the \#BlackLivesMatter communication network are shown in table 3 below:

Table 3. The Actors with Highest Outdegree in Communication Network of \#BlackLivesMatter Period 20 - 27 April 2021

\begin{tabular}{|c|l|c|}
\hline No. & \multicolumn{1}{|c|}{ Actors } & Outdegree \\
\hline 1. & jfsebastian146 & 60 \\
\hline 2. & radio_undergr & 16 \\
\hline 3. & bridget69176622 & 16 \\
\hline 4. & idek3339 & 13 \\
\hline 5. & collee02775798 & 12 \\
\hline
\end{tabular}

Sumber: Netlytic, 2021

Closeness centrality is the closeness that is created between the actors. The higher the closeness centrality is (closer to 1), the closer the actor is to other actors which will make the distribution of information easier (Rakhman, Ramadhani, \& Kuncoroyakti, 2021). In the \#BlackLivesMatter communication network, which was formed on April 20 - 27, there are 1,416 actors with a closeness centrality value of 1.00, including @mchristine55, @genecartwright,@beroot_,@legeaychristian and @brocbrock. The number is very large and Betweenness centrality is used to calculate how often an actor becomes an intermediary, mediator and facilitator for other actors on Twitter. Based on data taken through indicates that there is a closeness that occurs between the actors in the \#BlackLivesMatter communication network. The closeness that occurs makes the distribution of information about the hashtag fast, easy and wide. The presence of actors with closeness centrality also plays an important role in reaching out to important actors and main actors in the spread of \#BlackLivesMatter. The closeness between the actors shows that \#BlackLivesMatter is a popular hashtag that has become a part of Twitter users.

the Netlytic application, there are five actors with a fairly high betweenness value, namely @helloagain0611, @ collee02775798, @margare84784949, @Sparrowhybrid and 
(a) danielle 8691. The five actors have a betweenness value below 1 which means they are connecting actors but not too dominant. Even so, the five actors can be a successful intermediary to mediate and become facilitators for other actors who are directly involved in the \#BlackLivesMatter communication movement. The existence of this actor will assist in the process of disseminating information related to the hashtag. In addition, they also play a role in creating discussions in several clusters in the \#BlackLivesMatter communication network. The actor who has the highest betweenness centrality in the \#BlackLivesMatter communication network for the period $20-27$ April 2021 is shown in figure 2 and table 4 below:

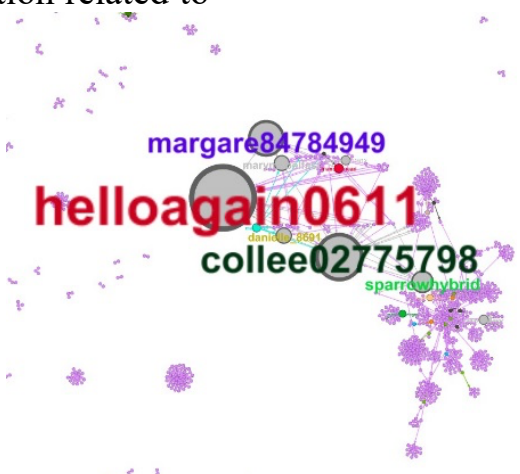

Figure 2. Betweenness Centrality \#BlackLivesMatter Period 20 - 27 April 2021

Source: Gephi Software

Table 4. Betweenness Centrality \#BlackLivesMatter Period 20 - 27 April 2021

\begin{tabular}{|l|l|l|}
\hline No. & \multicolumn{1}{|c|}{ Actors } & \multicolumn{1}{c|}{ Betweenness } \\
\hline 1. & helloagain0611 & 0.000049 \\
\hline 2. & collee02775798 & 0.000034 \\
\hline 3. & margare84784949 & 0.000025 \\
\hline 4. & Sparrowhybrid & 0.000015 \\
\hline 5. & danielle 8691 & 0.00001 \\
\hline
\end{tabular}

Sumber: Netlytic, 2021

Eigenvector centrality is used to measure how important the actors in a communication network are. Rakhman, Ramadhani, \& Fatoni (2021) state that actors who have high eigenvector centrality are a source of reference, conversation material, and as a pioneer or initiator of network formation and message distribution. In the \#BlackLivesMatter distribution, the important actors are @jeanmessiha, @cathygraphics2, @ rubnpulido,@jordanchariton and @ bradbeauregardj. The actor@jeanmessiha has the highest eigenvector centrality value, namely 1 . This value cannot be separated from the active role of the actors in spreading tweets using \#BlackLivesMatter.

@jeanmessiha is the most important actor in the \#BlackLivesMatter communication network for the period $20-27$ April 2021 . @jeanmessiha is the Twitter account of Jean Messiha, an economist and politician from France. He wrote a tweet criticizing BLM for not being able to voice all cases of racism, including the case of Sarah Halimi. The tweet posted by@jeansmessiha was against the BLM movement and received enough responses from other Twitter users to make it one of the important actors in the spread of \#BlackLivesMatter. In addition to @jeanmessiha, there are four other actors who have high eigenvector centrality values because they actively compose messages related to \#BlackLivesMatter. The actor with the highest eigenvector centrality in the \#BlackLivesMatter communication network for the period $20-27$ April 2021 is shown in figure 3 and table 5 below: 


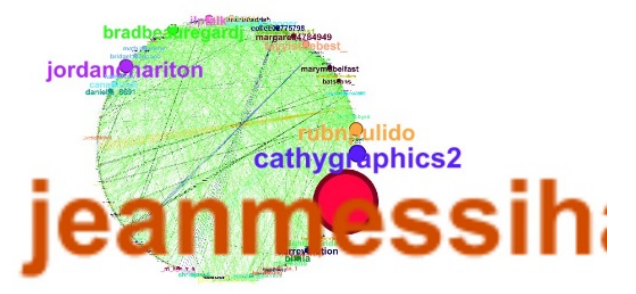

Figure 3. Eigenvector Centrality \#BlackLivesMatter Period 20 - 27 April 2021

Source: Gephi Software

Table 5. Eigenvector Centrality \#BlackLivesMatter Period 20 - 27 April 2021

\begin{tabular}{|l|l|l|}
\hline No. & Actors & Eigenvector \\
\hline 1 & jeanmessiha & 1.0 \\
\hline 2 & cathygraphics & 0.2706553209519094 \\
\hline 3 & rubnpulido & 0.21428571428571427 \\
\hline 4 & jordanchariton & 0.2130563241643512 \\
\hline 5 & bradbeauregardj & 0.16981498481745566 \\
\hline
\end{tabular}

Sumber: Netlytic, 2021

Analysis of the \#BlackLivesMatter Communication Network System Level for the Period 20-27 April 2021 Using Netlytic

System level analysis was conducted to find out how extensive the communication network is in spreading opinions about \#BlackLivesMatter. Using Netlytic.org, the researcher obtained the hashtag network structure at the system level for the period from April 20 to 27. There are 5 sizes used at the system level, namely diameter, density, reciprocity, centralization and modularity. The distribution and structure of the \#BlackLivesMatter network is shown in figure 4 and table 6 below:

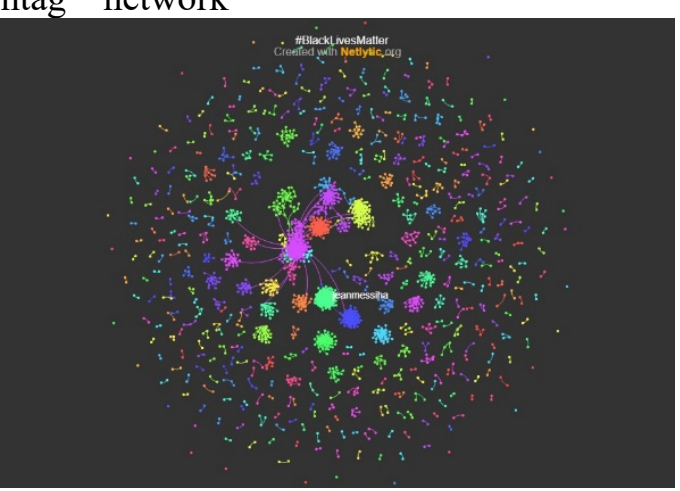

Figure 4. Visualization of \#BlackLivesMatter Network Structure

Period 20 - 27 April 2021

Source: Netlytic.org

Table 6. \#BlackLivesMatter Network Structure Period 20 - 27 April 2021

\begin{tabular}{ll}
\hline Analisis & Data \\
\hline Diameter & 42 \\
Density & 0.000391 \\
Reciprocity & 0.008777 \\
Centralization & 0.054110 \\
Modularity & 0.950800 \\
\hline
\end{tabular}

Source: Netlytic 
Diameter is the step or distance that a hashtag must travel to interact with members in a communication network. The larger the diameter value, the wider the reach of the hashtag and the longer the opinion spreads to members of the communication network. \#BlackLivesMatter has a diameter value of 42 , which means the hashtag can reach 42 steps for Twitter account owners. The value is quite small which means that a tweeted opinion can spread quickly but not too widely.

Density shows how much interaction or relationship that occurs between the actors. The low density value indicates that the interaction is only limited to mentions, retweets and replies in one direction to certain actors (Rakhman, Ramadhani, \& Fatoni, 2021). The \#BlackLivesMatter network structure density value is very low at only 0.000391 . A low value indicates that \#BlackLivesMatter is used by actors to express opinions which are then given a response in the form of mentions, retweets or replies in one direction without any dominant interaction.

Reciprocity is indicated by the mutual response between the actors. The higher the reciprocity value indicates the number of interactions or discussions that occur in a communication network. The reciprocity value of the \#BlackLivesMatter network structure is quite high, namely 0.008777 , which means that the hashtag is not only used to express opinions but is also used as a discussion between actors. This discussion is characterized by high reciprocity or interaction. Discussions about \#BlackLivesMatter took place on Twitter as a safe virtual public space for actors to discuss issues of the new social movement Black Lives Matter.

Centralization is the centralization that occurs in a communication network. This concentration is characterized by the presence of a central actor who dominates the conversation. The \#BlackLivesMatter communication network centralization value is 0.054110 . This value is small enough that \#BlackLivesMatter's spread is not driven by dominant actors and is only widely spread between actors. The small value of centralization shows that the digital opinion movement occurs quite freely and is not centered on certain actors (Rakhman, Ramadhani, \& Fatoni, 2021).

Modularity shows the number of clusters created in the distribution of a topic. Clusters that are formed usually have important actors who are driving the cluster. The
\#BlackLivesMatter modularity value is quite high, namely 0.950800 which indicates that the spread of the hashtag occurs into many clusters driven by several important actors. Each cluster has a different opinion about \#BlackLivesMatter which is then discussed with each other in the cluster. The high value of modularity indicates that many other actors are dominant where there are clusters that have different topics of conversation (Rakhman, Ramadhani, \& Kuncoroyakti, 2021).

Based on the analysis of the distribution of \#BlackLivesMatter at the actor level and system level, the hashtag has succeeded in creating a fairly wide communication network, driven by dominant actors in several clusters who have different opinions. This shows that \#BlackLivesMatter has become a topic of conversation that is quite often discussed by the public on social media so that it has succeeded in creating public opinion regarding the new social movement Black Lives Matter.

\section{Conclusions}

Opinions using \#BlackLivesMatter for the period 20-27 April 2021 are widely spread. The actor who has the highest degree of centrality is@jeanmessiha. The actor with the largest indegree is @jeanmessiha and the actor with the largest outdegree is @jfsebastian146. There are 1,416 actors who have closeness centrality. The number is very large which indicates that there is a closeness that occurs between the actors in the \#BlackLivesMatter communication network. The actor with the highest betweenness centrality is @ helloagain0611 and the actor with the highest eigenvector centrality is@jeanmessiha.

\#BlackLivesMatter is widely distributed and fast characterized by a fairly large diameter value. However, the spread of \#BlackLivesMatter does not have much interaction but quite often creates a reciprocal relationship between actors. The distribution of \#BlackLivesMatter does not have many dominant actors so it is spread into several clusters that have important actors and different opinions.

\section{References}

Anderson, M., Barthel, M., Perrin, A., \& Vogels, E. A. (2020). \#BlackLivesMatter surges on Twitter after George Floyd's death. Https://Www.Pewresearch.Org. https://www.pewresearch.org/fact$\operatorname{tank} / 2020 / 06 / 10 /$ blacklivesmatter-surges- 
on-twitter-after-george-floyds-death/

Anderson, M., Toor, S., Rainie, L., \& Smith, A. (2018). An analysis of \#BlackLivesMatter and other Twitter hashtags related to political or social issues. Https://Www.Pewresearch.Org.

https://www.pewresearch.org/internet/20 18/07/11/an-analysis-of-blacklivesmatterand-other-twitter-hashtags-related-topolitical-or-social-issues/

Bakry, G. N. (2020). Struktur Jaringan Pengguna Twitter dengan Tagar \#BandungLawanCovid19. Jurnal Komunikasi Global, 9(2).

Driver, S. (2021). Twitter for Business: Everything You Need to Know. Business News Daily. https://www.businessnewsdaily.com/748 8-twitter-for-business.html

Eriyanto. (2014). Analisis Jaringan Komunikasi Strategi Baru dalam Penelitian Ilmu Komunikasi dan Ilmu Sosial Lainnya. Prenadamedia Group.

Eriyanto. (2019). Hashtags and Digital Movement of Opinion Mobilization : A Social Network Analysis / SNA Study on \# BubarkanKPAI vs \# KamiBersamaKPAI Hashtags. Jurnal Komunikasi Indonesia, VIII(3).

Feeley, T. H., Lee, S., \& Chen, C. (Yixin). (2018). Communication Networks. In Encyclopedia of Health Communication (pp. 216-218). SAGE Publication.

Kurniawan, D., Iriani, A., \& Manongga, D. (2020). Pemanfaatan Social Network Analysis ( Sna ) Untuk Menganalisis Kolaborasi Karyawan Pada Pt. Arum Mandiri Group. Transformatika, 17(2), 149-159.

Lebron, C. J. (2017). The Making of Black Lives Matter: A Brief History of An Idea. In Prose Studies (Vol. 40, Issues 1-2). Oxford University Press. https://doi.org/10.1080/01440357.2019.1 656401

Maclean, F., Jones, D., Carin-Levy, G., \& Hunter, H. M. (2013). Understanding Twitter. British Journal of Occupational
Therapy,

$76(6)$

295-298. https://doi.org/10.4276/030802213X1370 6169933021

Rakhman, F. R., Ramadhani, R. W., \& Fatoni, A. (2021). Gerakan Opini Digital \# Indonesiaterserah Pada Media Sosial Twitter di Masa Pandemi Covid-19. Jurnal Penelitian Komunikasi, 24(1), 2944.

https://doi.org/10.20422/jpk.v24i1.752

Rakhman, F. R., Ramadhani, R. W., \& Kuncoroyakti, Y. A. (2021). Analisis Sentimen dan Opini Digital Kampanye 3M di Masa Covid-19 melalui Media Sosial Twitter. Jurnal Komunikologi, 18(01), 8-20.

Samsu. (2017). Metode Penelitian: (Teori dan Aplikasi Penelitian Kualitatif, Kuantitatif, Mixed Methods, serta Research \& Development) (Rusmini (ed.)). Pusat Studi Agama dan Kemasyarakatan (Pusaka).

Sataloff, R. T., Johns, M. M., \& Kost, K. M. (2011). Social Network Analysis: Theory and Applications. Code Pediapress.

Setatama, M. S., \& Tricahyono, D. (2017). Implementasi Social Network Analysis dalam Penyebaran Country Branding "Wonderful Indonesia." Ind. Journal on Computing, 2(2), 91-104. https://doi.org/10.21108/indojc.2017.22.1 83

Siyoto, S. (2015). Dasar Metodologi Penelitian (Ayup (ed.); Edisi pert). Literasi Media Publishing.

Tjahyana, L. J. (2019). Gerakan opini digital \#truebeauty pada twitter untuk pemeran film adaptasi komik webtoon.

Utami, A. B. (2018). Analisis Jaringan Komunikasi Kelompok. Di MCC Conference Proceeding.

Wicaksono, A., Kusumastuti, R. D., \& Prilantini, A. (2019). Jaringan Komunikasi dalam Meningkatkan Produktivitas Pelapak (Studi Kasus pada Komunitas Bukalapak Wilayah Jakarta). Jurnal Penelitian Komunikasi dan Opini Publik, 23(1), 25-39. 